\title{
LATE MAASTRICHTIAN CALCAREOUS NANNOFOSSIL CLIMATE RECORD AT QUSEIR REGION, RED SEA COAST, EGYPT: IS THAT LINKED TO DECCAN VOLCANISM?
}

\author{
Amr A. Metwally \\ Geology Department, Faculty of Science, Assiut University, Assiut 71516, Egypt \\ E-mail: amr.metwally@aun.edu.eg
}

\begin{abstract}
Calcareous nannofossil record of the Late Maastrichtian is analyzed at three sections at the Eastern Desert, Quseir region, Red Sea coast, Egypt. These sections are Gabal Anz, Gabal Atshan and Gabal Hamadat. Species richness as well as the relative abundance of sensitive nannofossil indicators throughout this interval signified remarkable climatic changes. It is indicated that the Late Maastrichtian is marked by cool climate that intersected by two warming episodes. The lower episode is marked by a drop in species richness as well as cool-water indicators concomitant with a positive shift of the warm-water species Micula decussata and M. murus. This event is interpreted as a response to sea-level fluctuations associated with an extreme oligotrophic condition of local environmental signal. The second episode corresponds to the latest Maastrichtian warming event. It is nearly has the same characteristics of the lower episode but it differs in the assemblage diversity. The nannofossil results during this event are correlated globally with similar observed findings. The main outcome of this correlation is the bloom of M. murus at the terminalMaastrichtian is contemporaneous with the observed acme at other localities. The possible drivers for such warming at the studied area throughout the latest Maastrichtian could be attributed to the double effect of the main phase of Deccan volcanism (Phase-2) that associated with sea-level fluctuations due to local tectonic activity. The climatic evolution of the interval preceding directly the Cretaceous/Paleogene $(\mathrm{K} / \mathrm{Pg})$ boundary cannot be traced due to the presence of hiatus.
\end{abstract}

Keywords: Calcareous nannofossil; Late Maastrichtian; climate change; Deccan volcanism, Quseir region; Egypt

\section{INTRODUCTION}

The 6.1 Million years of the Maastrichtian Stage (72.1- 66.0 Ma; Gradstein et al., 2012) witnessed global climatic changes that ended by the largest mass extinction through the Phanerozoic Earth's history at the Cretaceous/Paleogene (K/Pg) boundary (Mateo et al., 2017). A vast number of studies have been given much attention to the causes and consequences of the $\mathrm{K} / \mathrm{Pg}$ catastrophic event. While less attention has been given to the environmental and climatic conditions prior to the $\mathrm{K} / \mathrm{Pg}$ which probably leading to the $\mathrm{K} / \mathrm{Pg}$ mass extinction.

The pioneer studies of Li and Keller (1998 a, b), Abramovich and Keller (2003) have indicated that the Maastrichtian experienced remarkable climatic instabilities. These studies stated that the Maastrichtian is characterized by a generally cool climate that punctuated by two warming periods. The first is the Early/Late Maastrichtian transition (mid-Maastrichtian event) where the surface and bottom waters temperature increased by $2-3{ }^{\circ} \mathrm{C}$ (Li and Keller, 1998a, b; Abramovich and Keller, 2003). The second precedes the K/Pg boundary represented by the latest Maastrichtian warming greenhouse event which is globally documented (e.g. MacLeod et al., 2005; Tobin et al., 2012; Thibault and Gardin, 2006; 2007; 2010; Thibault and Husson, 2016), that witnessed an elevated in temperature by $4{ }^{\circ} \mathrm{C}$ ( $\mathrm{Li}$ and Keller, 1998a, b; Abramovich and Keller, 2003).

The rapid and dramatic climate changes that marked the latest Maastrichtian has been attributed by many authors to the main phase (phase-2) of Deccan volcanic activity (e.g. Tantawy et al., 2009; Punekar 
Mostafa T. F. and Lotfy M. M.

et al., 2014; Keller et al., 2016, 2018). Dessert et al., (2001), Cohen and Coe (2002) suggested that Deccan volcanism is responsible for the terminal-Maastrichtian warming throughout adding large quantities of $\mathrm{Co}_{2}$ into the atmosphere. In controversy with this suggestion, for example, the studies of Caldeira and Rampino (1990), Rampino and Self (2000), and Self et al., (2006) claimed that the amounts of $\mathrm{CO}_{2}$ added to the atmosphere by Deccan volcanism would not elevate the global temperatures more than $2{ }^{\circ} \mathrm{C}$ compared to the increase of $4^{\circ} \mathrm{C}$ in the ocean intermediate water temperature (Li and Keller, 1998a; Barrera and Savin, 1999) and $4^{\circ} \mathrm{C}$ on land (Wilf et al., 2003). The response of the calcareous nannofossil to the paleoclimatic changes throughout the Late Maastrichtian has been documented from different paleolatitudes (Pospichal and Wise, 1990; Lees, 2002; Thibault and Gardin, 2006, 2007, 2010; Sheldone et al., 2010). However, the Maastrichtian nannofossil record of the Egyptian sedimentary archive (low-latitude, southern Tethys margin) is less documented.

Generally, most of the nannofossil studies conducted on the Egyptian Maastrichtian sediments are focused on the paleoenvironmental changes in a narrow interval below and above the K/Pg boundary. On the other hand, very little studies including those of Tantawy (2003), Mandur and El-Ashwah (2015) investigated in detail Late Maastrichtian nannofossil. Thus, it is obvious that there is a gap regarding studying the nannofossil response to the Late Maastrichtian climatic changes. Furthermore, these studies did not highlight the causes for the climatic variability during the Late Maastrichtian. Consequently, the present study aims to; (1) fill this gap and highlight the response of the nannofossil population to the Late Maastrichtian climate and environmental changes via nannofossil quantitative analysis; (2) examine the hypothesis of Deccan volcanism as the main player that could be triggered the latest Maastrichtian warming episode. This examination is based on global correlation of the observed abundance pattern of Micula murus, the latest Maastrichtian warming indicator, with its similar finding at different paleolatitudes.

\section{MATERIAL, METHODS AND DEPOSITORY}

To realize the purposes of the present study, a total of 101 samples encompass the late Maastrichtian time interval are obtained from three sections arranged in north-south profile along the Red Sea coast, Quseir region, Eastern Desert, Egypt (Fig. 1). These sections are; (1) Gabal Anz (24 samples), located at $\sim 20 \mathrm{~km}$ north of Quseir City on Quseir-Safaga Road at (26. $10^{\prime} 22^{\prime \prime} \mathrm{N}$ and $\left.34^{\circ} 11^{\prime} 15^{\prime \prime} \mathrm{E}\right)$; (2) Gabal Atshan (32 samples) at $\sim 15 \mathrm{~km}$ west of Quseir at $\left(26^{\circ} 04^{\prime} 22^{\prime \prime} \mathrm{N}, 34^{\circ} 09^{\prime} 60^{\prime \prime} \mathrm{E}\right.$ ) and (3) Gabal Hamadat (45 samples) is located at $\sim 40 \mathrm{~km}$ west of Quseir at $\left(25^{\circ} 59^{\prime} 14^{\prime \prime} \mathrm{N}, 34^{\circ} 09^{\prime} 21^{\prime \prime} \mathrm{E}\right)$. In all the examined sections, the samples are collected at variable distances depending on the lithologic variations. The narrow sampling interval $(\sim 30 \mathrm{~cm}$ to $\sim 50 \mathrm{~cm})$ is always applied wherever lithologic changes are observed.

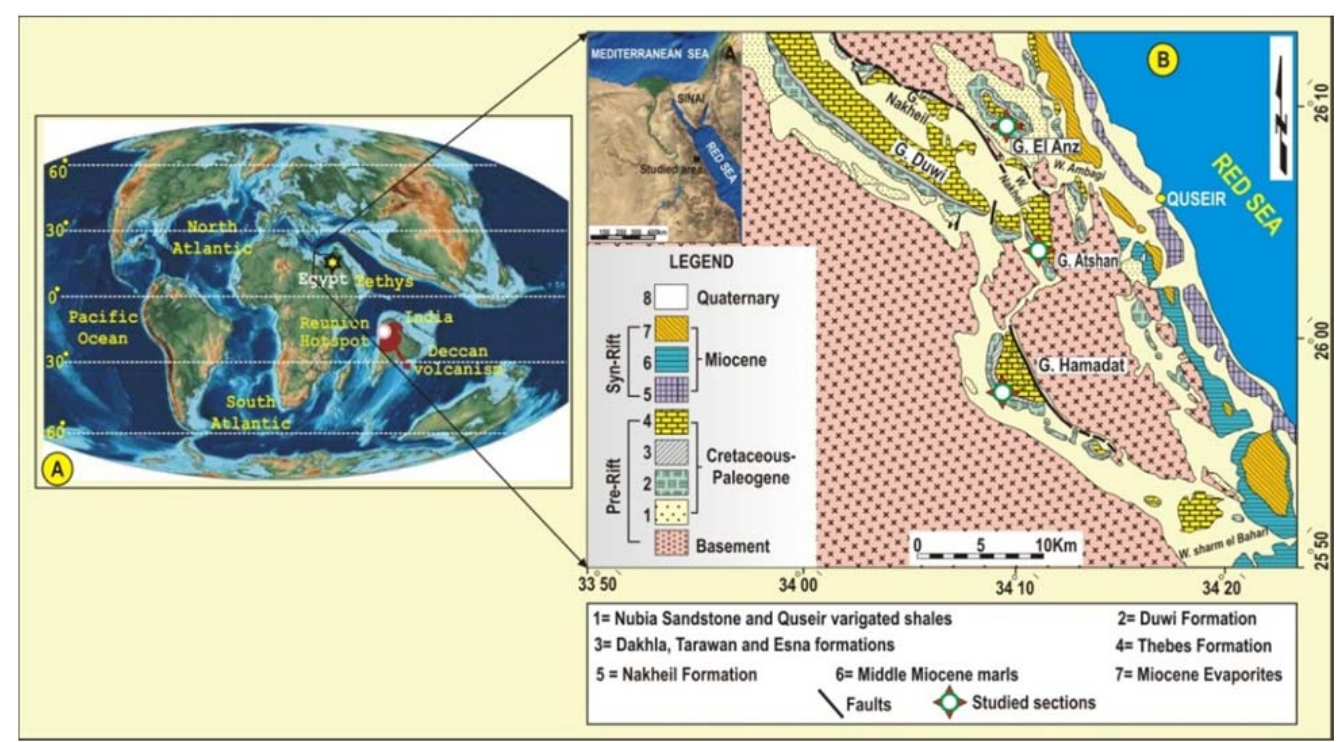

Fig. 1: A. Paleogeographic map shows the location of Egypt during the Late Maastrichtian (after Scotese, 2014 ); B. Geologic map of Quseir region, Red sea coast, shows the location of the studied sections (after Said, 1990). 


\section{Palynostratigraphical study of some Cretaceous rocks}

The calcareous nannofossil slides are prepared via standard smear slide preparation of Perch-Nielsen (1985). The prepared smear slides are investigated under 1250X magnification cross-polarized light microscope. Relative species abundance are calculated by counting at least 300 specimens along random traverses following the method of Jiang and Gartner (1986) as well as the abundance criteria used by Bralower and Mutterlose (1995) are also applied as follow: $\mathrm{A}=$ Abundance $>10$ specimens/field of view (fov); $\mathrm{C}=$ common 9-1 specimens/fov; $\mathrm{F}=$ few 9-1 specimens/ 1-9 fov; $\mathrm{R}=$ rare 1 specimen/ $>10$ fov. The preservation of the nannofossil taxa is descripted as follows: $G$ (Good): little or no overgrowth and no dissolution; M (Moderate): species show partly dissolution and overgrowth and P (Poor): species exhibit severe overgrowth and/or destruction of species (Figs. 2-4). Nannofossil species richness is presented as the total number of species counted in each sample. The taxonomic species concept of Perch Nielsen (1985) and Bown (1998) is applied in the present study. The calcareous nannofossil species identified throughout the studied interval are listed in the Appendix. Representative of the important nannofossil species recorded in the present study are illustrated in Plate I. The studied material are deposited in the collection of Dr. Amr A. Metwally, Geology Department, Faculty of Science, Assiut University, Assiut, Egypt. Code: Az, samples 1-25, for Gabal Anz section; At, samples 1-32, for Gabal Atshan section, and Hm, samples 1-45, for Gabal Hamadat section.

\section{GEOLOGIC SETTING AND LITHOSTRATIGRAPHY}

The study area is located at Quseir region and extended along the Red Sea coastal plain, two main types of sediments (pre- and syn-Red sea rift) are exposed together with the Precambrian basement as a consequences of rotated extensional fault blocks (Khalil and McClay, 2009).

The pre-rift exposures are assigned to Pre-Cambrian to Eocene in age. Generally, the Pre-rift sediments that extended from Upper Cretaceous to Lower Eocene are unconformably overlain the Pre-Cambrian basement rocks. The lower part of the Pre-rift sediments is composed of siliciclastic shallow marine to fluvial sandstones of Nubia Formation of the Upper Cretaceous age. This succession is overlain by mixed clastic and carbonate sediments of the Upper Cretaceous to Paleocene Quseir, Duwi, Dakhla, and Esna formations that overlain by massive limestones of the Thebes Formation (Fig. 1). The Syn-rift sediments are represented by different rock units that belong to Late Oligocene to Quaternary in age which rest unconformably over the Pre-rift sediments.

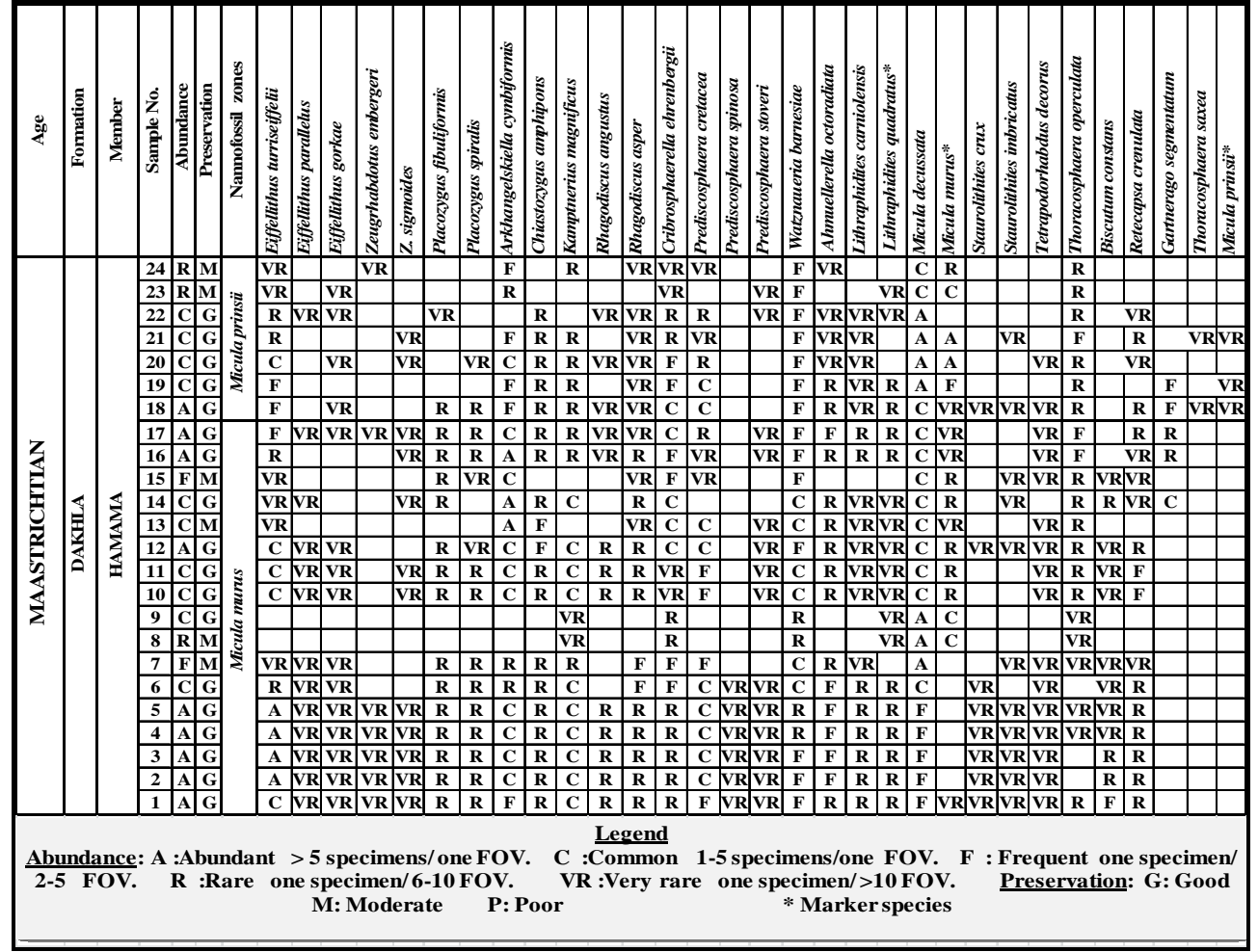

Fig. 2: Stratigraphic distribution chart of the common recorded calcareous nannofossil species throughout Late Maastrichtian at G. Anz section. 
Mostafa T. F. and Lotfy M. M.

Fig. 3: Stratigraphic distribution chart of the common recorded calcareous nannofossil species throughout Late Maastrichtian at G. Atshan section.
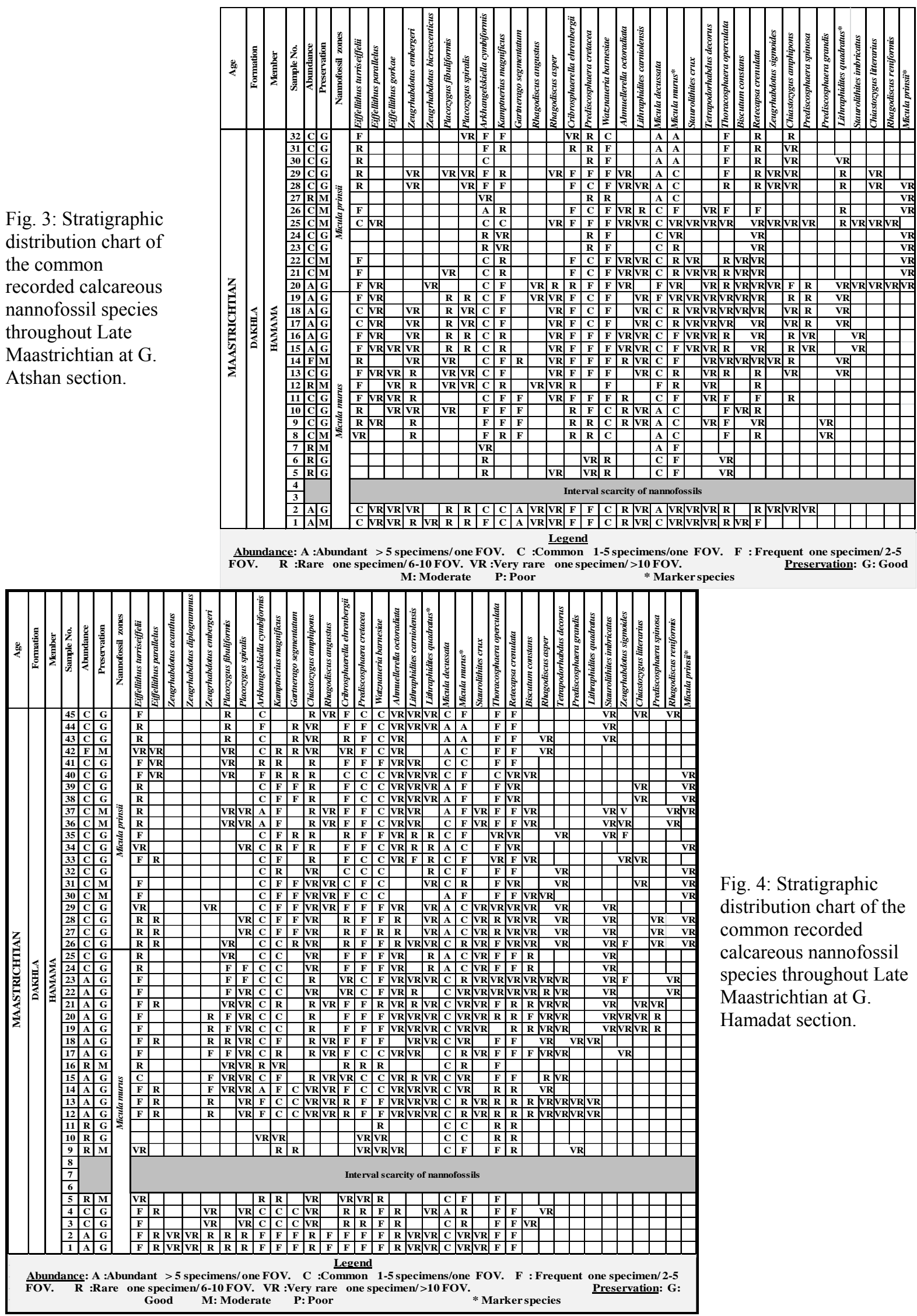

Fig. 4: Stratigraphic distribution chart of the common recorded calcareous nannofossil species throughout Late Maastrichtian at G. Hamadat section 


\section{Palynostratigraphical study of some Cretaceous rocks}

The sedimentary succession at the studied sections consists of five rock units corresponding to the Upper Cretaceous-Lower Paleogene. These units are arranged in stratigraphic order as Duwi, Dakhla, Tarawan, Esna, and Thebes formations.

The main interest of the present study is the Dakhla Formation of the Pre-rift sediments. The Dakhla Formation (Said, 1961) has a wide areal distribution all over the Egyptian provinces. At its type locality at Dakhla Oasis, Western Desert of Egypt, the Dakhla Formation consists of a thick succession of greenishgray, dark gray to black shales, intercalated with marl, marly limestone and calcareous fossiliferous mudstone beds. In addition, it is subdivided into three members, Mawhoob Shale (base), Beris Mudstone, and Kharga Shale members (Said, 1961). Following the classification of Abd El-Razik (1972), Dakhla Formation is classified into two members; Hamama (at the base) and Beida (at the top) members.

The present study is focused mainly on the lower part of the Dakhla Formation (Hamama Member) that encompasses the Late Maastrichtian interval. At all the studied sections, Hamama Member is composed of a succession of dark gray shale intercalated with calcareous shale, pink marl and marly limestone beds especially in its upper part (Fig. 5). Hamama Member attains about $36 \mathrm{~m}$ thick at G. Hamadat and G. Anz, while it reaches $\sim 17 \mathrm{~m}$ thick at G. Atshan (Figs. 6- 8). At all the studied sections, Hamama Member is unconformably overlain by Beida Member which assigned to Paleocene in age. The contact between Hamama and Beida members signifying the $\mathrm{K} / \mathrm{Pg}$ boundary is characterized by remarkable hiatus at the present study. Only the lowermost part of the Beida Member is included in the present study to ensure that the entire late Maastrichtian interval is represented. It is composed of dark gray and black shales that comprise $\sim 6 \mathrm{~m}, \sim 4 \mathrm{~m}$, and $\sim 2 \mathrm{~m}$ thick at G. Hamadat, G. Anz, and G. Atshan respectively (Figs. 6- 8).
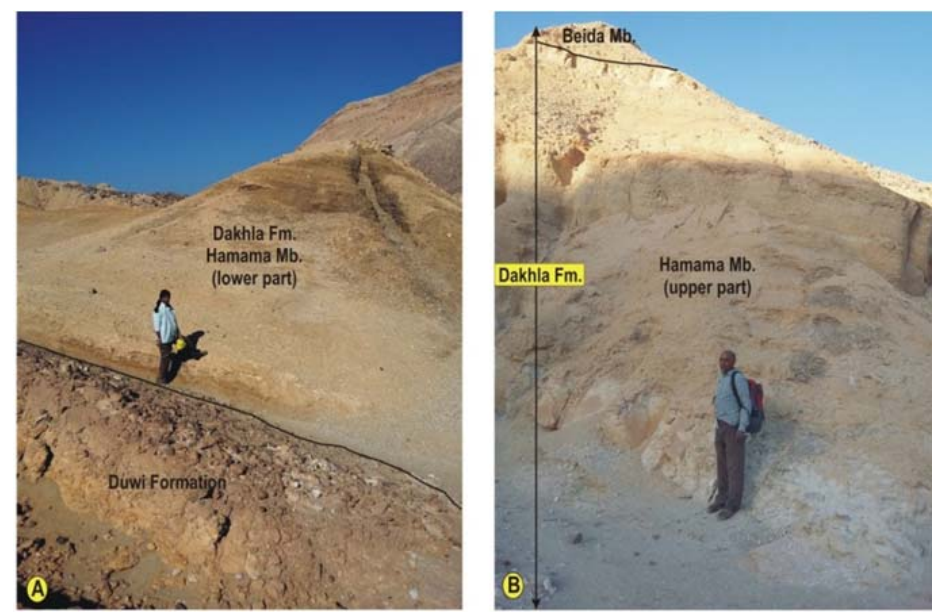

Fig. 5: Field photographs showing: A. the contact between Dakhla Formation (Hamama Member) and the underlying Duwi Formation at Hamadat section, B. the upper part of Hamama Member and the contact with the overlies Beida Member at Hamadat section, C. the contact between Hamama and Beida members at $\mathrm{G}$. Atshan section and the overlies Tarawan Formation, D. closed view shows the
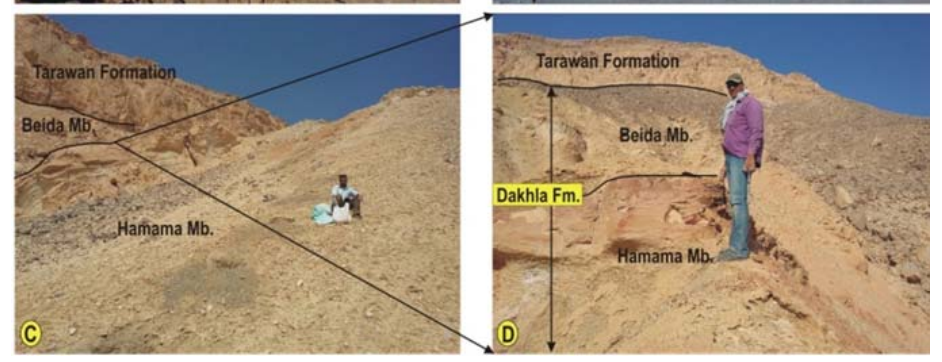
$\mathrm{K} / \mathrm{Pg}$ boundary (marl bed) at the contact between Hamama and Beida members at G. Atshan section.

\section{BIOSTRATIGRAPHY}

The biostratigraphic zonal scheme of Sissingh (1977) and the zones subdivisions suggested by PerchNielsen (1979a, 1983) for the Late Maastrichtian are followed at the present study. Generally, the nannofossil species recorded at the studied interval are abundant, moderate to well-preserved specimens. Nephrolithus frequens, the main marker species for the base of Subzone CC26a of Perch-Nielsen (1979a, 1983 ) is not recorded at the present study. Thus, the uses of this species as a zonal marker is not reliable at the present study. Instead of utilizing $N$. frequens, Micula murus the typical low-latitude marker species is 
Mostafa T. F. and Lotfy M. M.

used in the present study due to its reliability at the low-latitudes sites (e.g. Worsley and Martini 1970; Romein 1979; Perch-Nielsen 1985; Tantawy 2003). Consequently, based on the Lowest Occurrence (LO) of the nannofossil marker species, two zones are recorded representing the Late Maastrichtian; M. murus and M. prinsii. The stratigraphic distribution charts of the common recorded calcareous nannofossil are presented in figures 3-5

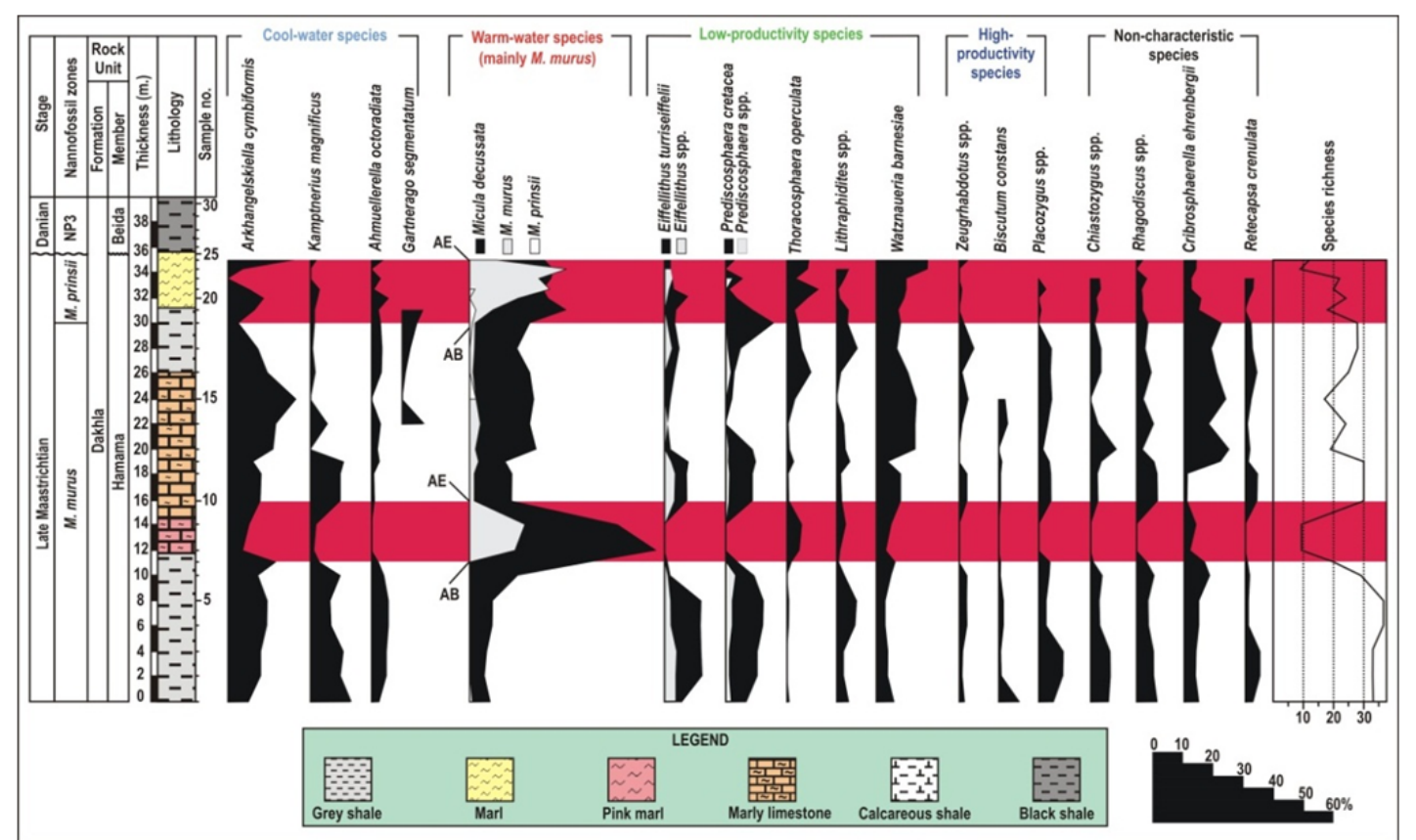

Fig. 6: Relative nannofossil abundance, species richness of most common nannofossil species recorded throughout the late Maastrichtian at G. Anz section. The transparent red lines indicate the observed warming episodes. Symbols of the lithostratigraphic rock units described in the study sections are indicated in the figure. $\mathrm{AB}=\mathrm{Acme} B$ eginning of Micula murus, $\mathrm{AE}=\mathrm{Acme}$ Ending of M. murus.

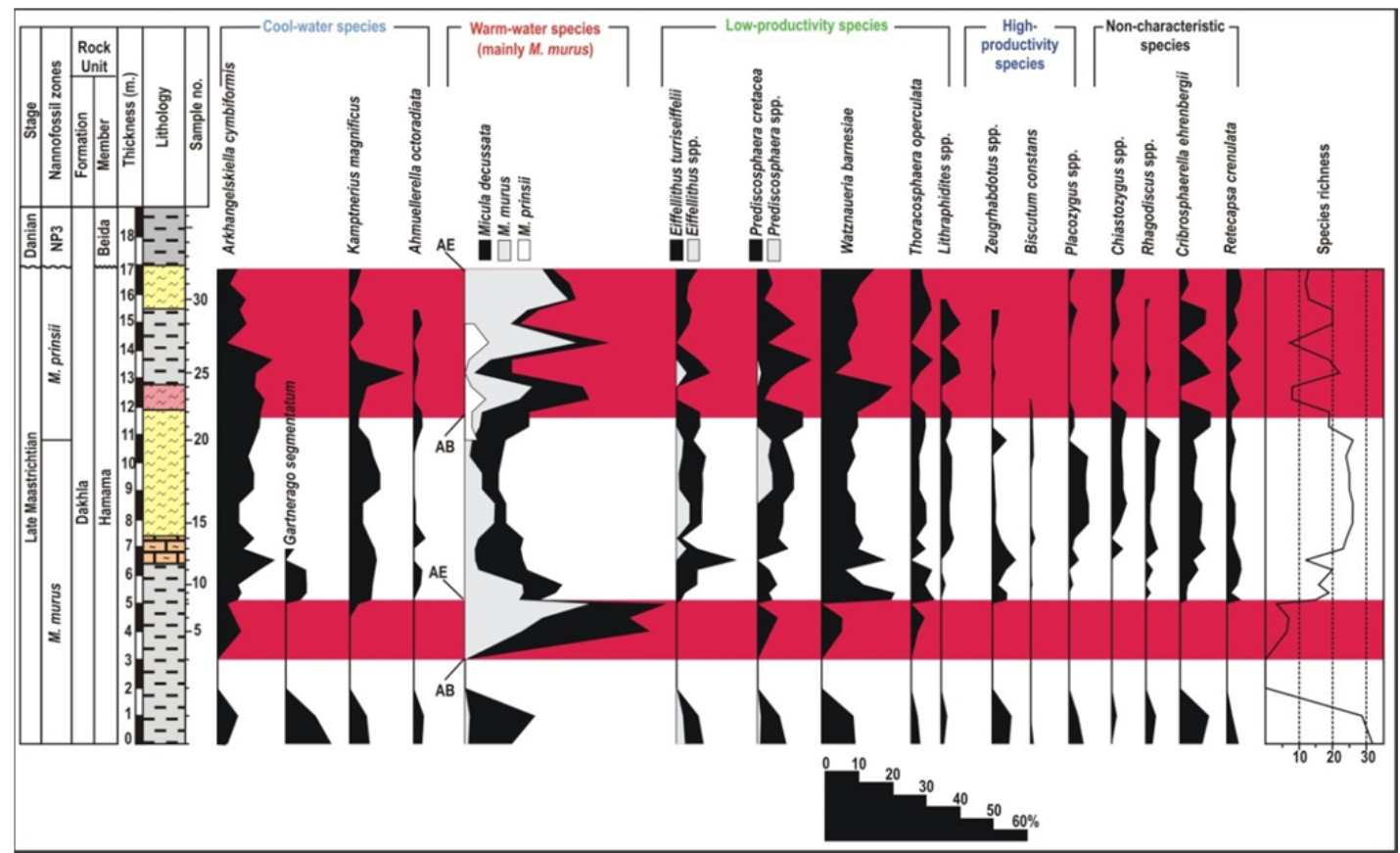

Fig. 7: Relative nannofossil abundance, species richness of most common nannofossil species recorded throughout the late Maastrichtian at G. Atshan section. The transparent red lines indicate observed warming episodes (for legend see Fig. 2). 
Palynostratigraphical study of some Cretaceous rocks

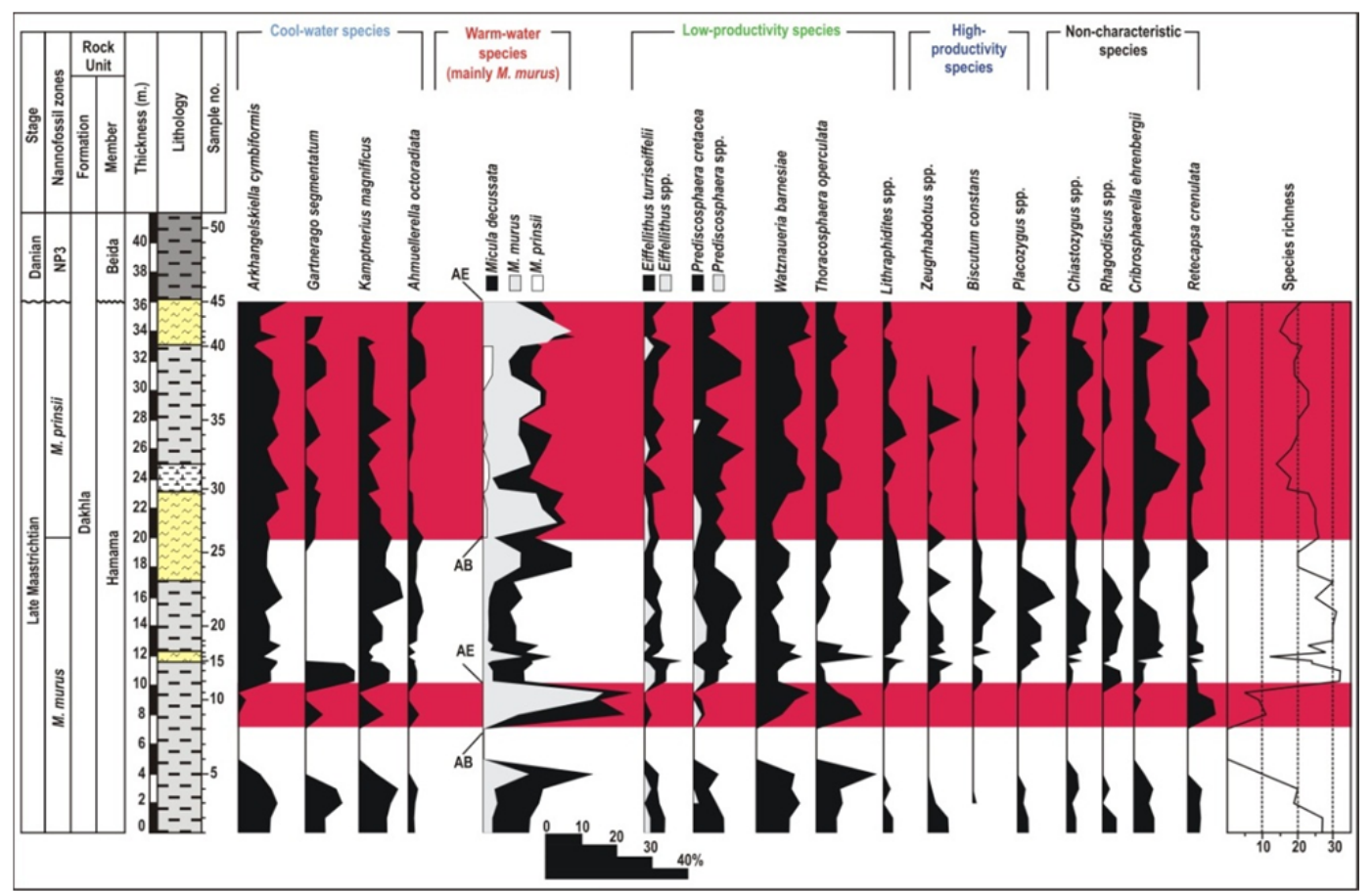

Fig. 8: Relative nannofossil abundance, species richness of most common nannofossil species recorded throughout the Late Maastrichtian at G. Hamadat section. The transparent red lines indicate observed warming episodes (for legend see Fig. 2).

\section{Micula murus Zone}

The M. murus Zone (Bukry and Bramlette 1970; emended Perch-Nielsen 1981) represents the interval between the LO of M. murus and the LO of M. prinsii. The zone is equivalent to the lower part of the $N$. frequens Zone of Cêpek and Hay (1969) and to the lower part of CC26 of Sissingh (1977). It spans the lower $\sim 30 \mathrm{~m}$ (samples nos. 1- 18), $\sim 11 \mathrm{~m}$ (samples nos. 1- 20), and $\sim 20 \mathrm{~m}$ (samples nos. 1- 26) thick at G. Anz, G. Atshan, and G. Hamadat, respectively (Figs. 3-5). The lower part of M. murus Zone is marked by an overall decrease in the nannofossil abundance as well as species richness except for the high common occurrence of $M$. decussata and $M$. murus. This pattern seems to be simultaneous at all studied sections (Figs. 6- 8).

\section{Micula prinsii Zone}

The M. prinsii Zone (Perch-Nielsen 1979b; emended Romein and Smit 1981) covers the stratigraphic interval from the LO of the nominate taxon to the Lowest Common Occurrence of Thoracosphaera spp. M. prinsii Zone is equivalent to the upper part of the $N$. frequens Zone of Cêpek and Hay (1969) and to the upper part CC26 of Sissingh (1977). It spans the upper part of Hamama member reaches $\sim 6 \mathrm{~m}$ thick at both G. Anz (samples nos. 18- 25) and G. Atshan (samples nos. 20-32), while it attains $\sim 16 \mathrm{~m}$ thick at G. Hamadat section (samples nos. 26- 45). This zone, is marked by the dominance occurrence of $M$. decussata and M. murus in addition to the moderate existence of Arkhangelskiella cymbiformis, Watznaueria barnesae, Cribrosphaerella ehrenbergii, Prediscosphaera spp., and Eiffellithus turriseiffelii (Figs. 3- 5). M. prinsii Zone is unconformably overlain by the Danian Chiasmolithus danicus (NP3) Zone at all studied sections which reflect a hiatus as mentioned previously (Figs. 6- 8).

\section{LATE MAASTRICHTIAN NANNOFOSSIL ASSEMBLAGE}

A total of 52 species are made up the bulk of the nannofossil assemblage recorded throughout the studied interval. The nannofossil assemblage shows moderate to well- preserved species throughout the studied materials. At all the studied sections, the nannofossil assemblage shows a similar composition but varied in the abundance magnitude. The quantitative analysis of the calcareous nannofossil species across the studied interval reflects the dominance of certain species that constitute about $60 \%$ of the assemblage. 
Mostafa T. F. and Lotfy M. M.

These species include; Micula decussata constitutes the main component of the Late Maastrichtian nannofossil assemblage. Two prominent peaks are observed, the first one attains up to $\sim 60 \%$ at the lower part, whereas the second builds-up to $\sim 40 \%$ at the topmost part of the studied interval. M. murus is relatively rare $(5 \%)$ in abundance throughout the lowermost part of the studied interval. The abundance markedly increases (up to $\sim 30 \%$ ) during the intervals that exhibit an increased abundance of M. decussata (Figs. 6- 8).

Watznaueria barnesae occurs in relatively low values at the lower part of the studied interval (lees than $\sim 10 \%$ ) and then increase and remains relatively high through the upper part of the late Maastrichtian to reach up to $\sim 20 \%$ (Figs. $6-8$ ).

Prediscosphaera cretacea reaches up to $\sim 15 \%$ of the total assemblage and displays an inverse relationship with $M$. decussata and $M$. murus. It is rather temporarily disappeared or decreased sharply in abundance coinciding with the maximum abundance of the former two taxa (Figs. 6- 8).Arkhangelskiella cymbiformis attains up to $\sim 20 \%$ of the total nannofossil assemblage. It displays a remarkable drop in abundance within the intervals that contained high abundance of M. decussata and M. murus. Kamptnerius magnificus constitutes about $15 \%$ of the assemblage and also exhibits a similar trend to A. cymbiformis. Eiffellithus turriseiffelii constitutes about $\sim 12 \%$ and remains relatively stable through its range (Figs. 68).

The other species that showed relatively low abundance ranging between $\sim 5 \%$ and a maximum of $\sim 10 \%$ and have a paleoenvironmental significance are considered in the interpretation. These species are represented by Ahmuellerella octoradiata, Gartnerago segmentatum, Thoracosphaera operculata, Lithraphidites spp., Zeugrhabdotus spp. and Biscutum constans. The representative of Placozygus spp., Chiastozygus spp., Rhagodiscus spp., Cribrosphaerella ehrenbergii, and Retecapsa crenulata are grouped as a non-characteristic species because they have no clear trends throughout the Late Maastrichtian interval (Figs. 6- 8). The species that constitute a relative abundance less than $\sim 2 \%$ are excluded from the interpretation but involved in the species richness calculation. They include Braarudosphaera bigelowii, Broinsonia verecundia, Cylindralithus serratus, Manivitella pemmatoidea, Microrhabdulus decorates, Prolatipatella multicarinata, Quadrum gartneri, Staurolithites spp., Tranolithus minimus, and Tetrapodorhabdus decorus.

\section{UPPER CRETACEOUS NANNOFOSSIL PALEOECOLOGICAL INDICES}

The nannofossil paleoecological indicators that used in the present study are those of well-documented paleoecological preferences. These sensitive indicators are assembled together under a specific group (Figs. 6- 8).

(1) Cool-water indicators, A. cymbiformis, K. magnificus, Ah. octoradiata and G. segmentatum are found in high abundance at high-latitude sites during the Cretaceous (Wind, 1979; Thierstein, 1981; Pospichal and Wise, 1990; Watkins, 1992; Lees, 2002).

(2) Warm-water indicator, the best indicator of the warm-surface water is Micula murus. This is indicated by the restricted occurrence to the low-latitudes warm tropical waters and entirely absent from the high-latitude regions (Worsley and Martini, 1970; Thierstein, 1981; Watkins et al., 1996; Lees, 2002).

(3) Productivity indicators, two distinctive groups of productivity have been established by Eshet and Almogi-Labin (1996) using statistical analyses; the low-productivity group encompasses Eiffelithus spp. (mainly E. turriseiffelii, Prediscosphaera cretacea, Lithraphidites spp. and Thoracosphaera operculata. Watznaueria barnesae is the abundant species throughout the Cretaceous and considered by many authors as a cosmopolitan species (e.g. Mutterlose, 1991; Mutterlose and Kessels, 2000) as well as preferred warm water temperature (e.g. Bukry, 1973; Huber and Watkins, 1992; Sheldon et al., 2010). However, its abundance pattern in the present study does not reflect a tendency to increased temperature. This is based on that $W$. barnesae does not fluctuate significantly and remains relatively stable during the warming events (Figs. 6- 8). On the other hand, a considerable number of studies 


\section{Palynostratigraphical study of some Cretaceous rocks}

have proposed W. barnesae as a low-productivity indicator (Roth and Krumbach, 1986; Erba et al., 1992; Williams and Bralower, 1995; Thibault and Gardin, 2006, 2007; 2010). Thus, the present study consideres $W$. barnesae as a low-productivity marker rather than a temperature index. The second group of Eshet and Almogi-Labin (1996) is the high-productivity indicators; it comprises Zeugrhabdotus spp., Biscutum spp. (mainly B. constans) and Thoracosphaera saxea. Roth and Bowdler (1981), Watkins (1989), Lees, et al., (2005) introduced Placozygus spp. (mainly P. spiralis) as a good indicator for mid and high-productivity conditions.

\section{DISCUSSION}

\section{Micula decussata: preservation signal or temperature marker?}

M. decussata is one of the principal constituents of the Late Maastrichtian assemblage at all studied sections. Its paleoecological affinity is a matter of debate since it showed different paleoecological interpretations. Several authors have interpreted $M$. decussata as a dissolution-resistant species (Thierstein, 1980, 1981) and hence as an indicator for poor preservation assemblage (e.g. Thierstein, 1980, 1981; Roth, 1983; Pospichal, 1991). This interpretation is not in agreement with the present study since it occurs among well-preserved nannofossil specimens even within the intervals that displayed blooms of $M$. decussata as well as low species richness. This is also supported by the occurrence of Watznaueria barnesae the dissolution-resistant taxon (Thierstein, 1980). Its abundance does not affect markedly within the intervals of high counts of $M$. decussata. Consequently, the uses of M. decussata as a sign for poor preservation or enhanced diagenetic process are not adequate but it reflects a paleoecological signal. Furthermore, the presence of $M$. decussata in high values among well-preserved assemblage has also been recognized by several authors (e.g., Eshet et al. 1992, Tantawy 2003; Thibault and Gardin, 2006). These authors suggested that the high occurrence of the former species indicates low-productivity and stressful marine conditions. At the present study, $M$. decussata peaks accompanied with the anomaly of $M$. murus (Figs. 6- 8). This refers that $M$. decussata tends to take over the assemblage during intervals of increased sea surface water temperature. Thus, based on its behavior during the interval of stressful conditions, it is suggested that $M$. decussata could be considered as a temperature marker that flourished during intervals of warming and extreme low-productivity conditions.

\section{Late Maastrichtian nannofossil climate record}

The quantitative analysis of the calcareous nannofossil assemblage during the Late Maastrichtian at the present study reflects climatic variability. The overall identified nannofossil assemblage reflects a period of cool climatic conditions that characterizes the Late Maastrichtian. It is indicated by the presence of a relatively high abundance of $A$. cymbiformis, the most common cool surface water indicator at the present study (Figs. 6- 8).

A. cymbiformis constitutes a relatively large proportion among the cool water species which represented by minor quantities of the high-latitude taxa, K. magnificus, A. octoradiata and $G$. segmentatum. This cool climatic trend is intersected by two conspicuous warming episodes. These episodes are simultaneous at all studied sections. The first one is observed at the lower part of M. murus Zone, while the second episode is nearly covered the whole M. prinsii Zone. These warming events are expressed by the unusual high abundance of M. murus and M. decussata (Figs. 6- 8). This pattern is combined with an overall decreased abundance of the cool-water species.

The first episode is the most striking event that marked by a sudden drop in the nannofossil species richness which builds up to $\sim 25-35$ species/sample below the warming event to reach $\sim 5-10$ species/sample within the event (Figs. 6- 8). Furthermore, the majority of species within this interval is temporarily disappeared or existed in fairly representatives except of $M$. murus and $M$. decussata. These species occurred in high values that constitute up to $\sim 30 \%$ and up to $\sim 60 \%$ of the total nannofossil assemblage respectively. The composition of this assemblage reflects stressful marine conditions that could be represented by a very shallow marine environment associated with an extreme low-productivity condition. The latter conditions could be explained at least in part by the massive occurrence of $M$. decussata beside the minor existence of the low-productivity indicators mainly $T$. operculata and $W$. barnesae at all studied sections (Figs. 6- 8). In addition, the high-productivity indicators are represented in 
Mostafa T. F. and Lotfy M. M.

very low abundance and/or not represented at all. Directly above this episode the nannofossil assemblage recovered to reach $\sim 15$ to $\sim 30$ species/sample, which indicates that the normal marine conditions being recovered.

The second warming episode is recorded within the latest Maastrichtian time interval. It is covered nearly the whole interval of M. prinsii Zone. It is marked by the decreased abundance of the cool water indicators coinciding with the dramatic increase of $M$. decussata (up to $\sim 40 \%$ ) and $M$. murus (up to $\sim 30 \%$ ). This event is relatively different than the previous one in containing relatively diverse assemblage which is not the case at the first warming event (Figs. 6- 8). The species richness during this event is relatively decreased to comprise up to $\sim 10-25$ species/sample. It is also worth to note that the nannofossil species richness remains relatively high during the cool climatic condition compared to its lower values throughout the warming events (Figs. 6- 8).

Resemble to the lower warming event, the latest Maastrichtian episode is marked by relatively high percentages of the low-productivity species especially $W$. barnesae that build up to $\sim 15 \%$ of the assemblage during this interval (Figs. 6- 8). This suggests that increased oligotrophication is associated with the warming events at the studied interval. The climatic conditions that prevailed within the interval preceding immediately the $\mathrm{K} / \mathrm{Pg}$ boundary cannot be traced due to the existence of notable hiatus. This hiatus is marked by the missing of the topmost part of $M$. prinsii and the earliest Danian Markalius inversus (NP1) and Cruciplacolithus tenuis (NP2).

\section{Is Deccan volcanism the main factor that triggered the latest Maastrichtian warming event at Quseir region?}

The latest Maastrichtian warming episode at the present study represents a time of high-stress conditions that could be possibly linked to global climate change. This interpretation is based on the observed acme of M. murus during the latest Maastrichtian at the present study (Fig. 9) which is simultaneous with the main phase of Deccan volcanism. The M. murus anomaly at the terminalMaastrichtian warming is observed at different paleo-latitudes (Thibault and Gardin, 2006, 2007, 2010; Thibault and Husson, 2016). This warming event is proposed to be linked to the global effect of Deccan volcanism in India (e.g. Courtillot et al., 1996; Ravizza and Peucker-Ehrenbrink, 2003). Chenet et al., (2007, 2008, and 2009) proposed that Phase-2, the main and most intensive phase of the Deccan volcanic activity represents a possible source of vast stressful environmental conditions that led to the $\mathrm{K} / \mathrm{Pg}$ boundary event.

To test the probability of the relationship between Deccan volcanism and terminal-Maastrichtian warming at the present study, a tentative correlation between the studied interval and other localities that recorded the same characteristics has been established. This correlation is considered as an extending to that published by Thibault and Husson (2016). It is based on the acme of M. murus, the latest Maastrichtian warming index. The timeline used in this correlation is the FO of M. prinsii (Fig. 9). Uses of this taxon as a timeline correlation is based on the validity of this species as a good marker for the latest Maastrichtian (Thibault and Husson, 2016). The compared sites include Equatorial Atlantic (ODP 1258A); South Atlantic (DSDP 525A); Central Pacific (DSDP 577A) of Thibault and Gardin (2006, 2007, and 2010); Indian Ocean (ODP 762C) of Thibault and Husson, (2016), Tethys sections include Bottaccione section, Italy (Gardin et al., 2012) and Elles section, Tunisia (Thibault et al., 2015). The authors of these studies proposed that the Deccan volcanic eruption (Phase-2) is responsible for the greenhouse warming during the latest Maastrichtian. However, the main outcome of this correlation is that the acme of M. murus in the present study is comparable to its similar observed acme at the compared sites (Fig. 9). This reflects that the increased abundance of M. murus during this interval has a global expression, which in turn could indicate a possible relationship between the latest Maastrichtian warming at the present study and the global effect of Deccan volcanism. Furthermore, the finding of the present study is supported by recent observations of Khozyem et al. (2019) at El-Beida section, Red sea coast, Quseir region, Egypt. They proposed a positive link between the environmental changes that predated and postdated the $\mathrm{K} / \mathrm{Pg}$ boundary hiatus and Phase-2 of Deccan volcanic activity. This suggestion is based on abiotic proxies including major changes among $\delta^{13} \mathrm{C}_{\text {org }}$ and TOC associated with mercury anomalous. An 


\section{Palynostratigraphical study of some Cretaceous rocks}

additional evidence that could makes Deccan volcanism a possible cause participated in the terminalMaastrichtian warming at the present study, is the paleogeographic position of Egypt. It is located proximity to the paleo-latitude of India (Fig. 1A) during this time interval as well as the Reunion hotspot which responsible for the massive Deccan volcanic eruption (Punekar et al., 2014). Punekar et al. (2014) documented three blooms of planktonic foraminifer high-stress Guembelitria during the Late Maastrichtian-early Danian at Gebel Qreiya and Wadi Hamama, Central Egypt. The most pronounced one $(>80 \%)$ is recorded in CF1 planktonic foraminiferal Zone at the latest Maastrichtian. During this interval an abrupt and rapid climate changes that correlative with Phase- 2 of the Deccan volcanism are observed.

However, the present correlation indicates that the lower warming event observed at the present study can be attributed to local environmental conditions which is not recognized at the other correlated sections (Fig. 9). Furthermore, a notable difference between the present study and the other compared localities regarding the presence/absence of the cool-water indicators throughout terminal-Maastrichtian warming is observed. At the present study, the cool-water species are suffered sharply from decreased in abundance and occurred in minor quantities. While the nannofossil population at Sites 1258A (western equatorial Atlantic), 525A (South Atlantic), and 577 (tropical Pacific), is characterized by the complete absence of the cool-water markers during the event (Thibault and Gardin, 2006, 2007, 2010).

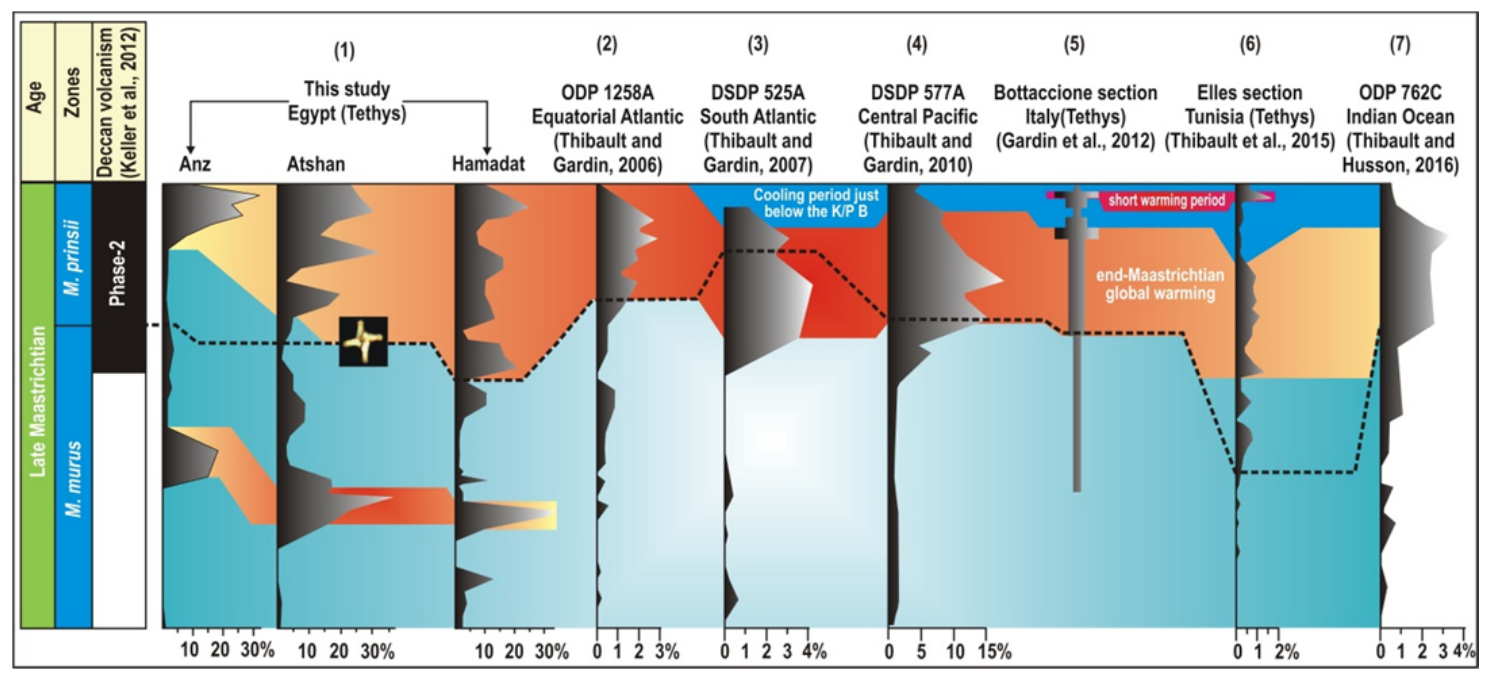

Fig. 9: Global correlation of the observed acme of M. murus of the present study, other Tethyan and intermediate latitudes sites that recorded similar acme during the Latest Maastrichtian time interval. The dashed line represents the timeline correlation that corresponds to the FO of M. prinsii. The transparent pale red line represents the warming episodes observed at the present study as well as the correlated sites.

This reflects that the response of the cool-water nannofossil indices to the terminal-Maastrichtian warming at the Tethyan sections differs from other localities. Also, the difference between the Tethyan region and other sites is also noticed by Thibault and Husson, (2016) regarding the short warming period that precedes directly the $\mathrm{K} / \mathrm{Pg}$ boundary which is not represented at the mid-latitude sites (Fig. 9).

A peculiar feature that recorded at the present study is the abnormal high percentages of M. murus which attains $\sim 30 \%$. Such a high abundance during this event has never been observed before at the compared localities (Fig. 9). However, given the formerly recorded percentages of M. murus, the maximum abundance during the terminal-Maastrichtian is recorded at DSDP Site 577A that reaches $>15 \%$ (Thibault and Gardin, 2010). Thus, such anomaly of this taxon at the present study cannot be only caused by the global climatic effect of the Deccan concerning the previously recorded values. The possible explanation for such enrichments could be attributed to the additional effect of the sea-level fluctuation and the associated lowered-productivity conditions during the latest Maastrichtian at the studied area (see part 7.2). The sea-level fluctuation at the studied area could be attributed to the tectonic framework of the Quseir region. This area is marked by an active tectonics during this time interval. This is indicated by the occurrence of a hiatus at the studied sections around the $\mathrm{K} / \mathrm{Pg}$ boundary which hampered the investigation of the climatic change prevailed during the interval that directly prior to the $\mathrm{K} / \mathrm{Pg}$ boundary. This tectonic 
Mostafa T. F. and Lotfy M. M.

activity could be resulted in a period of sea-level regression that reached its maximum at the terminal of the Cretaceous (K/Pg boundary) and resulted in such hiatus. Consequently, the proposed double effect of Deccan volcanism and sea-level fluctuation represents a possible explanation for the causes that triggered the terminal-Maastrichtian warming event and the abnormal values of M. murus at the present study.

\section{CONCLUSIONS}

Quantitative analysis of the Late Maastrichtian calcareous nannofossil assemblage at G. Anz, G. Atshan and G. Hamadat reveal notable climatic fluctuations. Generally, the overall climatic conditions at the studied interval is marked by cool climatic conditions which punctuated by two prominent warming episodes. The lower episode is marked by a dramatic drop in the species richness as well as cool-water indicators coinciding with bloom of $M$. decussata and M. murus. Also, minor amounts of the lowproductivity indicators are still represented. Whereas, the high-productivity indices are totally absent during this interval. This indicates that this episode is marked by stressful marine condition which could be attributed to a period of sea-level regression that coupled with increased oligotrophication.

The second episode corresponds to the latest Maastrichtian warming event. It is marked by an assemblage resembled to the previous one. The main difference between them is that species diversity does not decrease markedly throughout the second episode. The observed acme of $M$. murus at the present study is correlated with similar observed acme at different localities. The main finding of this correlation is that the observed acme of M. murus at the present study is coincident with its observed acme at the compared sites. This indicates that the latest Maastrichtian warming at the present study has a global nature. It is proposed that the main phase of Deccan volcanic activity could be a possible trigger for such warming event that effect the global marine ecosystem throughout this time interval.

The present study is also suggested that the Deccan volcanism is not only the main factor that caused the terminal-Maastrichtian warming at the studied interval. This is based on the unusual high abundance of M. murus. This extreme abundance is interpreted as a result of the double effect of the sea-level oscillation and the effect of Deccan volcanism during this time interval. The climatic and environmental conditions preceding directly the $\mathrm{K} / \mathrm{Pg}$ boundary are difficult to detect due to the presence of remarkable hiatus.

\section{REFERENCES}

Abdel-Razik, T. M. (1972): Comparative studies on the Upper Cretaceous-Early Paleogene sediments on the Red Sea coast, Nile Valley and Western Desert, Egypt. $6^{\text {th }}$ Arab Petroleum Cong., Algeria 71, 1-23.

Abramovich, S. and Keller, G. (2003). Planktonic foraminiferal response to the latest Maastrichtian abrupt warm event: a case study from South Atlantic DSDP Site 525A. Mar. Micropaleonto., 48 (3-4), 225-249.

Barrera, E. and Savin, S. M. (1999): Evolution of Campanian-Maastrichtian marine climates and oceans. In: Barrera, E., Johnson, C. C. (Eds.), Evolution of the Cretaceous Ocean Climate System: Sp. Publ. Geol. Soc. Am., 332, 245-282.

Bown, P. R. (1998): Calcareous Nannofossil Biostratigraphy. British Micropaleontology Soc. Publ. Ser. Chapman and Hall, London, $328 \mathrm{pp}$.

Bralower, T. and Mutterlose, J. (1995): Calcareous nannofossil biostratigraphy of ODP Site865, Allison Guyot, Central Pacific Ocean: a tropical Paleogene reference section. Proceedings of the Ocean Drilling Program, Scientific Results, volume 143, 31-72.Washington, DC: US Government Printing Office.

Bukry, D. (1973): Coccolith and silicoflagellate stratigraphy, Tasman Sea and southwestern Pacific Ocean, Deep Sea Drilling Project Leg 21. Initial Reports of the DSDP 21, 885-893.

Bukry, D. and Bramlette, M.N. (1970): Coccolith age determinations, Leg 3, Deep Sea Drilling Project. In: Maxwell, A. E., Von Herzen, R.P., et al. (Eds.), Initial Report DSDP 3, 589-11.

Caldeira, K. and Rampino, M.R. (1990): Carbon dioxide emissions from Deccan volcanism and a K/T boundary greenhouse effect. Geophysics Result Letters, 17 (9), 1299-1302.

Cêpek, P. and Hay, W. W. (1969): Calcareous nannoplankton and biostratigraphic subdivisions of the Upper Cretaceous. Transactions of the Gulf Coast Association of Geolog. Societ., 19, 323-336. 


\section{Palynostratigraphical study of some Cretaceous rocks}

Chenet, A. L., Quidelleur, X., Fluteau, F., Courtillot, V. and Bajpai, S. (2007): 40K/40Ar dating of the main Deccan large igneous province: further evidence of Cretaceous-Tertiary boundary age and short duration. Ear. Planet. Scien. Lett., 263, 1-15.

Chenet, A. L., Fluteau, F., Courtillot, V., Gérard, M. and Subbarao, K.V. (2008): Determination of rapid Deccan eruptions across the Cretaceous-Tertiary boundary using paleomagnetic secular variation: results from a 1200-m-thick section in the Mahabaleshwar escarpment. J. Geophys. Resear. Solid Earth, 113 (B4).

Chenet, A. L., Courtillot, V., Fluteau, F., Gerard, M., Quidelleur, X., Khadri, S.F.R., Subbarao, K.V. and Thordarson, T. (2009): Determination of rapid Deccan eruptions across the Cretaceous-Tertiary boundary using paleomagnetic secular variation: 2 . Constraints from analysis of eight new sections and synthesis for a 3500-m-thick composite section. J. Geophys. Resear. Solid Earth, 114 (B6).

Cohen, A.S. and Coe, A.L. (2002): New geochemical evidence for the onset of volcanism in the Central Atlantic magmatic province and environmental change at the Triassic-Jurassic boundary. Geol., 30 (3), $267-270$.

Courtillot, V., Jaeger, J. J., Yang, Z., Feraud, G. and Hofmann, C. (1996): The influence of continental flood basalts on mass extinctions; where do we stand? In: Ryder, G., Fastovsky, D., Gartner, S. (Eds.), The CretaceousTertiary Event and other Catastrophes in Earth history. Geolo. Soc. of America, Special Paper 307, Boulder, 513-525.

Dessert, C., Dupré, B., François, L. M., Schott, J., Gaillardet, J., Chakrapani, G., and Bajpai, S. (2001): Erosion of Deccan Traps determined by river geochemistry: impact on the global climate and the 87Sr/86Sr ratio of seawater. Ear. Planet. Sci. Lett., 188, 469-474.

Erba, E., Castradori, F., Guasti, G. and Ripepe, M. (1992): Calcareous nannofossils and Milankovitch cycles: the example of the Gault Clay Formation (southern England). Palaeogeogr., Palaeoclimatol., Palaeoecol., 93, 47-69.

Eshet, Y. and Almogi Labin, A. (1996): Calcareous nannofossils as paleoproductivity indicators in Upper Cretaceous organic rich sequences in Israel. Mar. Micropaleontol., 29, 37-61.

Eshet, Y., Moshkovitz, S., Habib, D., Benjamini, C. and Magaritz, M. (1992): Calcareous nannofossil and dinofagellate stratigraphy across the Cretaceous/Tertiary boundary at Hor Hahar, Israel. Mar. Micropaleontol., 18, 199-228.

Gardin, S., Galbrun, B., Thibault, N., Coccioni, R. and Premoli Silva, I. (2012): Biomagnetochronology for the upper Campanian-Maastrichtian from the Gubbio area, Italy: new results from the Contessa Highway and Bottaccione sections. Newsl. Stratigr., 45, 75-103.

Gradstein, F. M., Ogg, J. G., Schmitz, M. and Ogg, G. (2012): The Geologic Time Scale 2012. Elsevier, Boston, USA, 1176.

Huber, B. T. and Watkins, D. K. (1992): Biogeography of Campanian-Maastrichtian calcareous nannoplankton in the region of the Southern Ocean: paleogeographic and paleoclimatic implications. In: Kennett, J. P., Warnke, D. A. (Eds.), The Antarctic Paleoenvironment: A Perspective on Global Change: Antarctic Research Series, 56. American Geophysical Union, Washington, D.C, 31-60.

Jiang, M.J., and Gartner, S. (1986): Calcareous nannofossil succession across the 1009 Cretaceous/Tertiary boundary in east-central Texas. Micropaleont., 32, 232-255.

Keller, G., Adatte, T., Bhowmick, P. K., Upadhyay, H., Dave, A., Reddy, A. N., Jaiprakash, B. C. (2012): Nature and timing of extinctions in Cretaceous-Tertiary planktic foraminifera preserved in Deccan intertrappean sediments of the Krishnae Godavari Basin, India. Ear. Planet. Scie. Lett., 341, 211-221.

Keller, G., Punekar, J. and Mateo, P. (2016): Upheavals during the late Maastrichtian: volcanism, climate and faunal events preceding the end-Cretaceous mass extinction. Palaeogeogr., Palaeoclimatol., Palaeoecol., 441,137-151.

Keller, G., Mateo, P., Punekar, J., Khozyem, H., Gertsch, B., Spangenberg, J., Bitchong, A. M. and Adatte, T. (2018): Environmental changes during the Cretaceous Paleogene mass extinction and Paleocene-Eocene Thermal Maximum: Implications for the Anthropocene. Gond. Rese., 56, 69-89

Khalil S.M. and McClay K.R. (2009): Structural control on syn-rift sedimentation, northwestern Red Sea margin, Egypt. Mar. and Petrol. Geolo., 26, 1018-1034. 
Mostafa T. F. and Lotfy M. M.

Khozyem, H., Tantawy, A. A., Mahmoud, A., Emam, A. and Adatte, T. (2019): Biostratigraphy and geochemistry of the Cretaceous-Paleogene $(\mathrm{K} / \mathrm{Pg})$ and early danian event (Dan-C2), a possible link to deccan volcanism: New insights from Red Sea, Egypt. J. of Afr. Ear. Scien., 160, 103645.

Lees, J. A. (2002): Calcareous nannofossils biogeography illustrates palaeoclimate change in the Late Cretaceous Indian Ocean. Creta. Rese., 23, 537-634.

Lees, J. A., Bown, P.R. and Mattioli, E. (2005): Problems with proxies? Cautionary tales of calcareous nannofossil paleoenvironmental indicators. Micropaleont., 51 (4), 333-345.

Li, L. and Keller, G. (1998a): Maastrichtian climate, productivity and faunal turnovers in planktic foraminifera of South Atlantic DSDP Sites 525A and 21. Mar. Micropaleont., 33 (1-2), 55-86.

Li, L. and Keller, G. (1998b) Abrupt deep-sea warming at the end of the Cretaceous. Geolo., 26, 995-998.

MacLeod, K. G., Huber, B.T. and Isaza-Londoño, C. (2005): North Atlantic warming during "global" cooling at the end of the Cretaceous. Geolo., 33,437 440.

Mandur M. and El-Ashwah, A. (2015): Calcareous nannofossil biostratigraphy and paleoecology of the Maastrichtian in the western coast of the Gulf of Suez, Egypt. Arab. J. of Geosci., 8, 2537-2550.

Mateo, P., Keller, G., Punekar, J., and Spangenberg, J., (2017): Early to Late Maastrichtian environmental changes in the Indian Ocean compared with Tethys and South Atlantic. Palaeogeogr., Palaeoclimatol., Palaeoecol., 478, 121-138.

Mutterlose, J. (1991): Das Verteilungs-und Migrationsmuster des kalkigen Nannoplanktons in der borealen Unterkreide (Valangin-Apt) NW Deutschlands. Palaeontograp., B221, 27-152.

Mutterlose, J. and Kessels, K. (2000): Early Cretaceous calcareous nannofossils from high latitudes: implications for palaeobiogeography and palaeoclimate. Palaeogeogr., Palaeoclimatol., Palaeoecol., 160, 347-372.

Perch-Nielsen, K. (1979a): Calcareous nannofossils from the Cretaceous between the North Sea and the Mediterranean. IUGS Series A, 6, 223-272.

Perch-Nielsen, K. (1979b): Calcareous nannofossil zonation at the Cretaceous-Tertiary boundary in Denmark. Proc. Cretaceous-Tertiary Boundary Events Symposium, Copenhagen, 1:115-135.

Perch-Nielsen, K. (1981): Les nannofossiles calcaires á la limite Crétacé-Tertiaire près de El Kef, Tunisie. Cah. Micropaleontologie, 3, 25-37.

Perch-Nielsen, K. (1983): Recognition of Cretaceous stage boundaries by means of calcareous nannofossil. In: T. Birkelund, et al. (eds.), Symposium on Cretaceous Stage Boundaries, Copenhagen, Abstracts, 152-156.

Perch-Nielsen, K. (1985): Mesozoic calcareous nanofossils. In: Bolli, H.M., Saunders, J.B., PerchNielsen, K. (Eds.), Plankton Stratigraphy. Cambridge University Press, Cambridge.

Pospichal, J. J. (1991): Calcareous nannofossils across the Cretaceous/Tertiary boundary at Site 752, eastern Indian Ocean, In: Weissel, J., Peirce, J., et al. (Eds.), Project ODP Sci. Resul., 121, 395-414.

Pospichal, J. J. and Wise Jr., S. W. (1990): Calcareous nannofossils across the K-T boundary, ODP Hole 690C, Maud Rise, Weddell Sea. Proceeding ODP Scie. Resul., 113, 515-532.

Punekar, J., Keller, G., Khozyem, H., Hamming, C., Adatte, T., Tantawy, A. A. and Spangenberg, J. E. (2014): Late Maastrichtian-early Danian high-stress environments and delayed recovery linked to Deccan volcanism. Cret. Rese., 49, 63-82.

Rampino, M.R. and Self, S. (2000): Volcanism and biotic extinctions. In: Sigurdsson, H. (Ed.), Encyclopedia of Volcanoes. Academic Press, New-York, 1083-1091.

Ravizza, G. and Peucker-Ehrenbrink, B. (2003): Chemostratigraphic Evidence of Deccan Volcanism from the Marine Osmium Isotope Record. Scien., 302, 1392-1395.

Romein, A. J. T. (1979): Lineages in Early Paleogene calcareous nannoplankton. Utre. Micropaleontol. Bull., 22,1-231.

Romein, A. J. T. and Smit, J. (1981): The Cretaceous/Tertiary boundary: calcareous nannofossils and stable isotopes. Paleontol. Proc., 84, 295-314.

Roth, P. H. (1983): Calcareous nannofossils in mid-Cretaceous black shale cycles from the Atlantic and Pacific: effects of diagenesis. EOS, 64, 733-734

Roth, P. H. and Bowdler, J. L. (1981): Middle Cretaceous calcareous nannoplankton biostratigraphy and oceanography of the Atlantic Ocean. In: Warme, J.E., Douglas, R.G., Winterer, E.L. (Eds.), The Deep 


\section{Palynostratigraphical study of some Cretaceous rocks}

Sea Drilling Project: A Decade of Progress: Special Publication, Soc. of Econo., Paleontol. Mineral., 32, 517-546.

Roth, P. H. and Krumbach, K. R. (1986): Middle Cretaceous nannofossil biogeography and preservation in the Atlantic and Indian Oceans: implications for palaeoceanography. Mar. Micropaleontol., 10, 235266.

Said, R. (1961): Tectonic framework of Egypt and its influence on distribution of foraminifera. Amer. Assoc. Petrol. Geol., Bull., 45, 198-218.

Said, R. (1990): The geology of Egypt. Rotterdam: Balkema, 734p

Scotese, C.R. (2014): Atlas of Late Cretaceous Maps, PALEOMAP Atlas for ArcGIS, volume 2, The Cretaceous, Maps 16 - 22, Mollweide Projection, PALEOMAP Project, Evanston, IL.

Self, S. and Thordarson, T. J. (2006): Volatile fluxes during flood basalt eruptions and potential effects on the global environment: a Deccan perspective. Earth Planet. Sci. Lett., 248 (1-2), 518-532.

Sheldon, E., Ineson, J. and Bown, P. (2010): Late Maastrichtian warming in the Boreal Realm: Calcareous nannofossil evidence from Denmark. Palaeogeogr., Palaeoclimatol., Palaeoecol., 295, 55-75.

Sissingh, W. (1977): Biostratigraphy of the Cretaceous Nannoplankton. Geolgie en. Minjbouw, 56, 37-65.

Tantawy, A. A. (2003): Calcareous nannofossil biostratigraphy and paleoecology of the CretaceousTertiary transition in the Western Desert of Egypt. Mar. Micropaleontol., 47, 323-356.

Tantawy, A., Keller, G., and Pardo, A. (2009): Late Maastrichtian Volcanism in the Indian Ocean: Effects on Calcareous Nannofossils and Planktic Foraminifera. Palaeogeogr., Palaeoclimatol., Palaeoecol., 284, 63-87.

Thibault, N. and Gardin, S. (2006): Maastrichtian calcareous nannofossil biostratigraphy and paleoecology in the Equatorial Atlantic (Demerara Rise, ODP Leg 207 Hole 1258A). Rév. de micropaléontol., 49, $199-214$.

Thibault, N. and Gardin, S. (2007): The late Maastrichtian nannofossil record of climate change in the South Atlantic DSDP Hole 525A. Mar. Micropaleontol., 65, 163-184.

Thibault, N. and Gardin, S. (2010): The calcareous nannofossil response to the end Cretaceous warm event in the Tropical Pacific. Palaeogeogr., Palaeoclimatol., Palaeoecol., 291, 239-252.

Thibault, N. Husson, D. (2016): Climatic fluctuations and sea-surface water circulation patterns at the end of the Cretaceous era: Calcareous nannofossil evidence. Palaeogeogr., Palaeoclimatol., Palaeoecol.,441, 152-164.

Thibault, N., Galbrun, B., Gardin, S., Minoletti, F., Le Callonnec, L. (2015): The end Cretaceous in the southwestern Tethys (Elles, Tunisia): orbital calibration of paleoenvironmental events before the mass extinction. In. J. Earth. Sci. http://dx. doi.org/10.1007/s00531-015-1192-0.

Thierstein, H. R. (1980): Selective dissolution of Late Cretaceous and Earliest Tertiary calcareous nannofossils: experimental evidence. Cret. Res., 2, 165-176.

Thierstein, H. R. (1981): Late Cretaceous nannoplankton and the change at the Cretaceous/Tertiary boundary. SEPM Spec. Publ., 32, 355-394.

Tobin, T. S., Ward, P. D., Steig, E. J., Olivero, E. B., Hilburn, I. A., Mitchell, R. N., Diamond, M. R., Raub, T. D. and Kirschvink, J. L. (2012): Extinction patterns, $\delta 18 \mathrm{O}$ trends, and magnetostratigraphy from a southern high-latitude Cretaceous Paleogene section: links with Deccan volcanism. Palaeogeogr., Palaeoclimatol., Palaeoecol., 350-352, 180-188.

Watkins, D. K. (1989): Nannoplankton productivity fluctuations and rhythmically bedded pelagic carbonates of the Greenhorn Limestone (Upper Cretaceous). Palaeogeogr., Palaeoclimatol., Palaeoecol.,74, 75-86.

Watkins, D. K. (1992): Upper Cretaceous nannofossils from Leg 120, Kerguelen Plateau, Southern Ocean. Procee. ODP Scient. Resul., 120, 343-370.

Watkins, D. K., Wise Jr., S. W., Pospichal, J. J. and Crux, J. (1996): Upper Cretaceous calcareous nannofossil biostratigraphy and paleoceanography of the Southern Ocean. In: Moguilevsky, A., Whatley, R. (Eds.), Microfossils and oceanic environments. University of Wales, Aber. Press, 355-381.

Wilf, P., Johnson, K. R. and Huber, B. T. (2003): Correlated terrestrial and marine evidence for global climate changes before mass extinction at the Cretaceous-Paleogene boundary. Proc. National Acad. Sci. U. S. A., 100 (2), 599-604. 
Mostafa T. F. and Lotfy M. M.

Williams, J. R. and Bralower, T. J. (1995): Nannofossil assemblages, finefraction stable isotopes, and the paleoceanography of the Valanginian-Barremian (Early Cretaceous) North Sea Basin. Paleoceanogr., $10,815-839$.

Wind, F. H. (1979): Maestrichtian-Campanian nannofloral provinces of the southern Atlantic and Indian Oceans. In: Talwani, M., Hay, W.W., Ryan, W.B.F. (Eds.), Deep Drilling Results in the Atlantic Ocean: Continental Margins and Paleoenvironment. AGU, Maur. Ewi. Ser., 3, 123-137.

Worsley, T. and Martini, E. (1970): Late Maastrichtian nannoplankton provinces. Nature 225, 1242-1243.

\section{Appendix A.}

Alphabetical list of the nannofossil species recorded in the present study. References not listed in the text can be found in Persh-Nielsen (1985) and Bown (1998)

Ahmuellerella octoradiata (Gorka, 1957) Reinhardt (1966)

A. regularis (Gorka, 1957) Reinhardt and Gorka (1967)

Arkhangelskiella cymbiformis Vekshina (1959)

Biscutum constans (Gorka, 1957) Black in Black and Barnes (1959)

B. magnum Wind and Wise in Wise and Wind, (1977)

B. notaculum Wind and Wise in Wise and Wind, (1977)

Braarudosphaera bigelowii (Gran and Braarud, 1935) Deflandre, (1947)

Broinsonia verecundia Wind and Wise in Wise and Wind (1977)

Chiastozygus amphipons (Bramlette and Martini, 1964) Gartner (1968).

C. antiquus (Perch-Nielsen, 1973) Burnett (1998)

C. litterarius (Gorka, 1957) Manivit (1971)

Cribrosphaerella ehrenbergii (Arkhangelsky, 1912) Deflandre in Piveteau (1952)

Cylindralithus serratus Bramlette and Martini (1964)

Eiffellithus gorkae Reinhardt (1965)

E. parallelus Perch-Nielsen (1973)

E. turriseiffelii (Deflandre in Deflandre and Fert, 1954) Reinhardt (1965)

Gartnerago segmentatum (Stover, 1966) Thierstein (1974)

Kamptnerius magnificus Deflandre (1959)

Lithraphidites carniolensis Deflandre (1963)

L. grossopeetinatus Bukry (1969)

L. quadratus Bramlette and Martini (1964)

Manivitella pemmatoidea (Deflandre in Manivit 1965) Thierstein (1971)

Microrhabdulus decoratus Deflandre (1959)

Micula decussata Vekshina (1959)

M. praemurus (Bukry, 1973) Stradner and Steinmetz (1984)

M. murus (Martini, 1961) Bukry (1973)

M. prinsii Perch-Nielsen (1979)

Placozygus fibuliformis (Reinhardt, 1964) Hoffmann (1970)

Pl. spiralis (Bramlette and Martini, 1964) Hoffmann (1970)

Prediscosphaera arkhaneiskyi (Reinhardt, 1965) Perch-Nielsen (1984) 
Palynostratigraphical study of some Cretaceous rocks

Pr. cretacea (Arkhangelsky, 1912) Gartner (1968)

Pr. grandis Perch-Nielsen (1979)

Pr. spinosa (Bramlette and Martini, 1964) Gartner (1968)

Pr. stoveri (Perch-Nielsen, 1968) Shafik and Stradner (1971)

Prolatipatella multicarinata Gartner (1968)

Retacapsa crenulata (Bramlette and Martini, 1964) Grün in Grün and Allemann (1975)

Retacapsa ficula (Stover, 1966) Burnett (1998b)

Rhagodiscus angustus (Stradner, 1963) Reinhardt (1971)

R. asper (Stradner, 1963) Reinhardt (1967)

R. reniformis Perch-Nielsen (1973)

R. splendans (Deflandre, 1953) Verbeek (1977)

Staurolithites crux (Deflandre and Fert, 1954) Caratini (1963)

S. imbricatus (Gartner, 1968) Burnett (1998)

Tetrapodorhabdus decorus (Deflandre in Deflandre and Fert, 1954) Wind and Wise in Wise and Wind (1977)

Thoracosphaera operculara Bramlette and Martini (1964)

T. saxea Stradner (1961)

Tranolithus minimus (Bukry, 1969) Perch-Nielsen (1984)

Watznaueria barnesae (Black, 1959) Perch-Nielsen (1968)

W. biporta Bukry (1969)

Zeugrhabdotus acanthus Reinhardt (1965)

Z. bicrescenticus (Stover, 1966) Burnett in Gale et al., 1996

Z. embergeri (Noël, 1959) Perch-Nielsen (1984)

Z. sigmoides (Bramlette and Martini, 1964) Bown and Young (1997) 
Mostafa T. F. and Lotfy M. M.

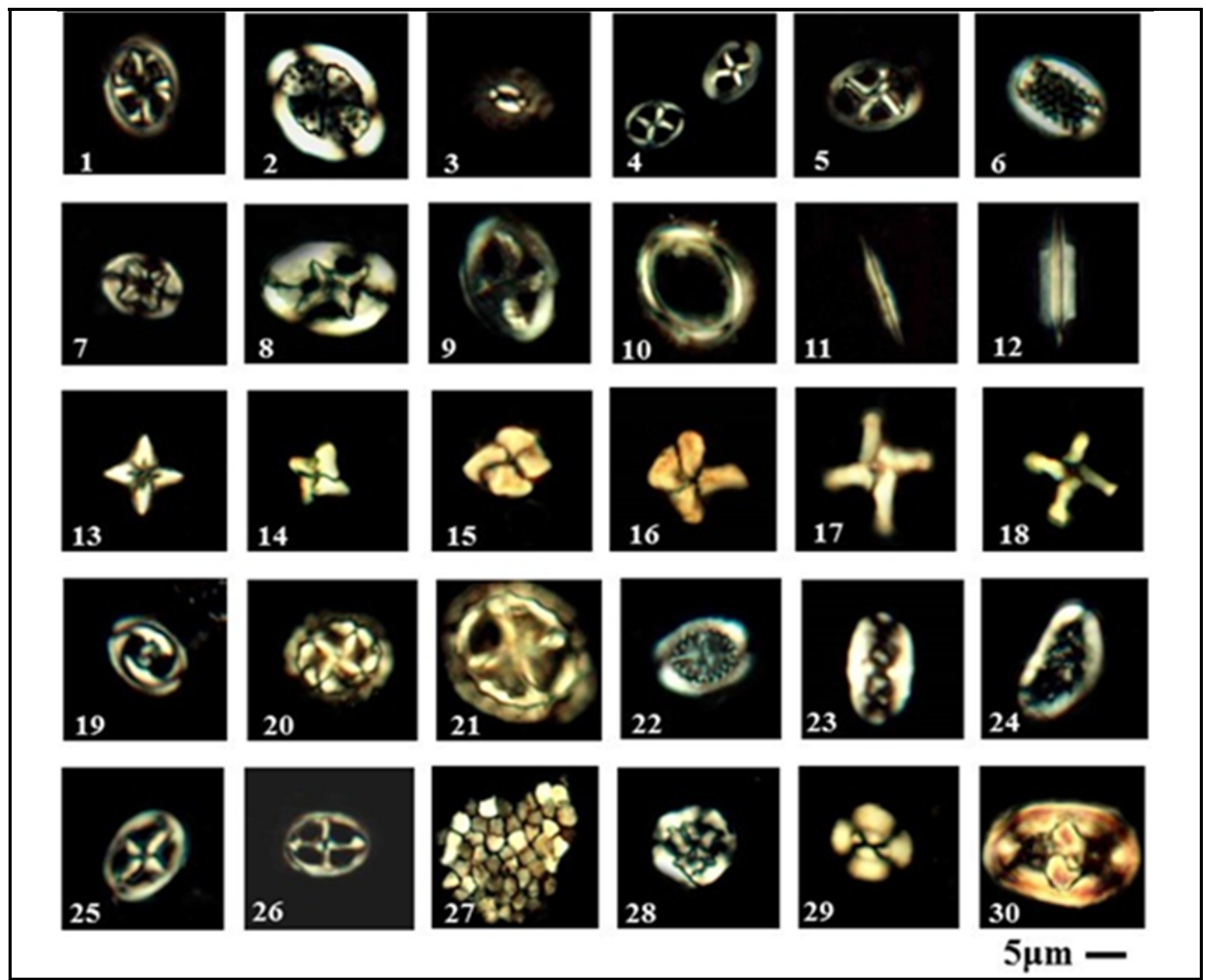

Plate I: Light microscope images of selected nannofossil taxa recorded from the Late Maastrichtian interval at the studied sections. 1. Ahmuellerella octoradiata, sample no. 20, G. Hamadat section; 2. Arkhangelskiella cymbiformis, sample no. 4, G. Hamadat section; 3. Biscutum constans, sample no. 14, G. Anz section; 4. Chiastozygus amphipons, sample no. 16, G. Atshan section; 5. C. litterarius, sample no. 20, G. Atshan section; 6. Cribrosphaerella ehrenbergii, sample no. 29, G. Atshan section; 7. Eiffellithus parallelus, sample no. 40, G. Hamadat section; 8. E. turriseiffelii, sample no. 2, G. Hamadat section; 9. Gartnerago segmentatum, sample no. 13, G. Hamadat section; 10. Kamptnerius magnificus, sample no. 25, G. Atshan section; 11. Lithraphidites carniolensis, sample no. 21 , G. Hamadat section; 12. L. quadratus, sample no. 20, G. Hamadat section; 13. Micula decussata, sample no. 8, G. Anz section; 14. M. murus, sample no. 24, G. Anz section; 15. M. murus, sample no. 11, G. Hamadat section; 16. M. murus, sample no. 30, G. Atshan section; 17-18. M. prinsii, sample no. 39, G. Hamadat section; 19. Placozygus fibuliformis ample no. 22, G. Hamadat section; 20. Prediscosphaera cretacea, sample no. 13, G. Anz section; 21. Pr. Grandis, sample no. 8, G. Atshan section; 22. Retacapsa crenulata, sample no. 17, G. Anz section; 23. Rhagodiscus angustus, sample no. 12, G. Atshan section; 24. R. reniformis, sample no. 22 , G. Hamadat section; 25. Staurolithites crux, sample no. 18, G. Anz section; 26. S. imbricatus, sample no. 14, G. Anz section; 27. Thoracosphaera operculara, sample no. 17, G. Anz section; 28. T. saxea, sample no. 40, G. Hamadat section; 29. Walznaueria barnesae, sample no. 11, G. Hamadat section; 30. Zeugrhabdotus embergeri, sample no. 11, G. Hamadat section. 
Palynostratigraphical study of some Cretaceous rocks

السجل المناخى للهوائم الجيريه متناهية الصغر التى سجلت من الماسترختي المتأخر في منطقة القصير، ساحل البحر

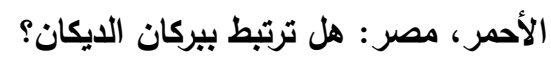

$$
\text { قسم الجيولوجيا - كلية العلوم - جامعة أسيوط عبدالصبور متولي }
$$

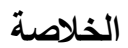

السجل المناخي لحفريات الهوائم الجيريه متتاهية الصغر التى سجلت من الماسترختي المتأخر نم تحليله في ثلاث

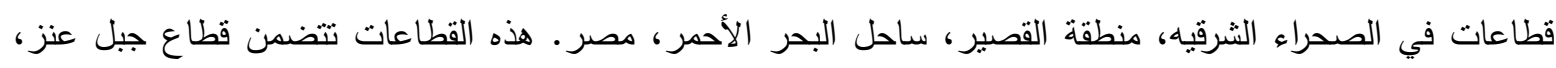
جبل عطشان، جبل حماضات.

ثراء الإنواع والوفره النسبيه للحفريات الجيريه الهائمه متتاهية الصغر الداله على التغير المناخي نتشير إلى تغير كبير في

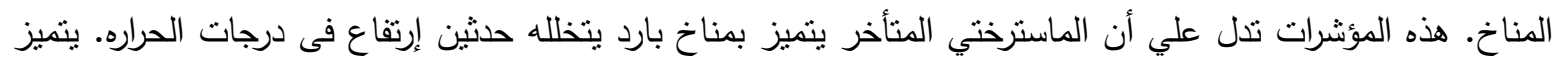

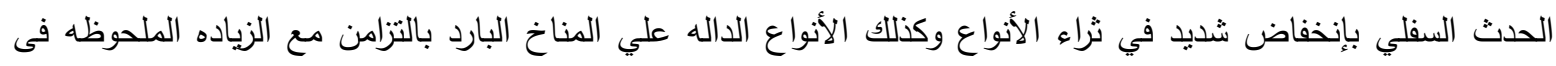

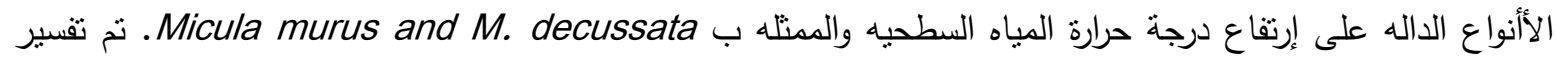
هذا الحدث علي حدث محلي نتيجة لنزبزب مستوي سطح البحر والذي صاحبه ظروف بيئيه صعبه تتميز بنقص الغذاء.

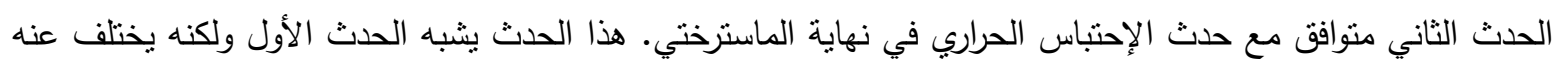

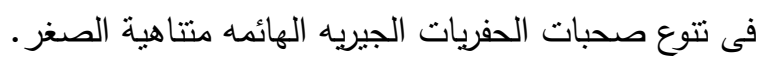
نتائج الحفريات الجيريه متتاهية الصغر خلال الحدث الثاني تمت مضاهاتها عالمياً. النتيجه الرئيسيه لهذه المضاهاه هو أن الزياده الملحوظه في نسب نواجد (M. murus) فى نهاية الماسترختي في القطاعات محل الدراسه منزامنه مع منيلاتها

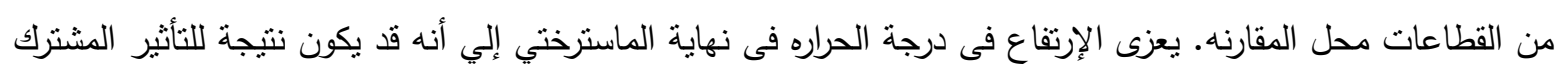
لبركان الديكان (المرحله الثانية الرئيسيه) المصاحبه للتغير المحلي في منطقة الدراسه نتيجة عمليات تكتونيه. التطور المناخي خلال الفتره التي تسبق مباشرة الحد الفاصل بين الطبانشيرى/الباليوجين من الصعب تفسيره نظراً لوجود ثغره زمنيه. 